\begin{tabular}{ccc}
\hline International Journal of Engineering \& Technology, $7(3.25)(2018) 16-20$ \\
SPC \\
Website $:$ www.sciencepubco.com/index.php/IJET \\
Research paper
\end{tabular}

\title{
Usage of Online Learning Resources Among Academic Staff at Malaysian University
}

\author{
Kamilah Radin Salim*, Morina Abdullah, Nor Liza Ali, Rosmah Ali \\ Universiti Teknologi Malaysia, Kuala Lumpur, Malaysia \\ *Corresponding author E-mail: kamilah.kl@utm.my
}

\begin{abstract}
This paper reports on the awareness and usage of online learning resources in teaching and learning among the academic staff at a public university in Malaysia. In addition, the advantages and disadvantages of online learning resources are also presented. Online learning resources recommended by the management of the university include e-learning modules, Open Courseware (OCW), Massive Open Online Courses (MOOC), BLOSSOMS, Edutainment and Video of Exemplary Professionals. Data were collected using a survey questionnaire with Likert scale items and open-ended questions. The questionnaires were distributed to 160 academic staff of the university. The results show that the most attended training was e-learning and most respondents are currently implementing it in their courses. However, less than $10 \%$ of the respondents implemented the OCW, MOOC, BLOSSOMS and Edutainment. About $23.1 \%$ of the respondents implemented Video of Exemplary Professionals in their teaching and learning. Some respondents also reported lack of student participation in using e-learning and other resources due to system instability. The practical implication of this study is that more training on new online learning resources should be provided to the academic staff to increase their skills in using the online learning resources in their teaching. Better internet connection is also necessary to boost the use of these resources.
\end{abstract}

Keywords: blended learning, e-learning, online learning resources; online teaching and learning strategies; teachers' training

\section{Introduction}

In the era of information and communication technology (ICT), most of students in higher education institutions are already exposed to the use of ICT. Consequently, the higher education institutions need to reform the teaching and learning approaches by using technologies in their class to complement face-to-face teaching and learning. The use of ICT in education also expands the opportunities for learning and access to online learning resources without the constraints of time and place. Therefore, this case study was performed to examine the awareness and implementation of online learning resources in teaching among the academic staff at one public university in Malaysia.

The use of online learning resources in teaching and learning is part of the blended learning program in the New Academia Learning Innovation (NALI) Model promoted via the top-down approach by the management of the university. NALI is part of teaching and learning policy of the university. The objective of NALI is to create meaningful and interactive learning activities, materials, environments and systems appropriate to develop Graduate Student Attributes (1). NALI Model emphasizes pedagogy and the use of digital resources as shown in Figure 1. Examples of pedagogy (also known as Learning Modes) are case study teaching, problem-based learning, peer instruction, and service learning; whereas examples of digital resources (also known as Learning Materials) are Open Courseware (OCW), Massive Open Online Courses (MOOC), and BLOSSOMS. However, this paper only discusses the academic staff's awareness and implementation of online learning resources (or digital resources) in their teaching.

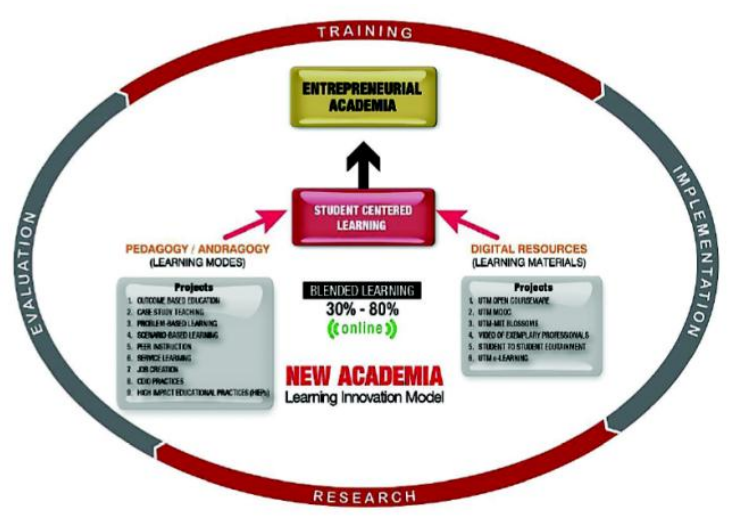

Fig. 1: New Academia Learning Innovation (NALI) Model (2)

Blended learning is a combination of face-to-face and online teaching and learning approaches that foster meaningful learning experience for the students (2). Therefore, all courses offered by all programs at the university are required to have e-learning component. Academic staff are given points in their performance appraisal to encourage them to use the online learning resources in their teaching.

The university also has Center for Teaching and Learning (CTL) that provides training and workshops for staff development. The mission of CTL is "Promoting Excellence and Innovative in T\&L". All training for new teaching and learning approaches, use of ICT in teaching and learning and other related educational training are provided by CTL. 
With all these strategies in place, it is interesting to see how NALI Model was perceived and implemented by the academic staff. Therefore, the objectives of this study were to:

1. Assess the awareness of the academic staff on various online learning resources in NALI Model;

2. Identify which online learning resources in NALI Model are being practised by the lecturers;

3. Highlight the advantages and disadvantages of online learning resources in NALI Model.

\section{Literature Review}

Studies pertaining to the use of technologies, known as Information and Communication Technologies (ICT), in the classroom in the late 1990s indicated issues of inaccessibility of resources in schools (3-6); the lack of training at the pre-service level in using ICT (7); and teachers' lack of confidence to use the computer (8, 9). Recent review also indicates almost similar issues plaguing the initiative on the use of technologies in the classroom although the concept has been introduced for more than two decades. (10) carried out an extensive survey concerning teachers who were involved in "TeachUp!" in 44 districts in the USA to examine teachers' perceptions on the use of technologies in their teaching and learning. TeachUp! is a technology empowerment program to educate teachers in the USA to use technologies in the classroom. The findings showed that teachers, including newer and from digital native generations, did not have adequate technological proficiency needed to take advantage of the technologies; thus making them unable to effectively use the technologies in the classroom. Based on their findings, the authors suggested that teachers, including newer teachers from digital native generations must be taught on how their acquired skills can be used to integrate technology into the classroom.

Similar in aspiration in enhancing teaching and learning in Malaysia, Frog VLE, a cloud-based virtual learning environment, where teachers, students and parents can participate was introduced in Malaysian schools in 2013 (11). By 2015, 10,000 selected primary and secondary schools had participated in this program (12). This program is supported by the Ministry of Education. Therefore, teachers were expected to use them in their classroom. However, (13) reported that teachers were still slow in taking advantage of the use of technologies in teaching and learning because of time constraint and the issues on accessibility to technology and computer laboratories.

At the higher education level, various Open Educational Resources (OER) or online learning resources such as Open Courseware (OCW) and Massive Open Online Courses (MOOC) have been introduced to support online learning. Online learning is an important strategy to improve access to courses and flexibility in higher education that benefits the student and the institution (14). However, (15) reported that one of the main obstacles in using the online learning resources among the instructors in higher learning institutions was time constraint.

One of the earliest form for online learning is e-learning, which was introduced in 1999(16). E-learning is a computer-based educational tool or system, delivered through the internet that enables learners to learn from anywhere and at any time. Through elearning, the teachers could share their teaching materials with their students in various formats such as videos, slideshows, word documents and PDFs. Features in e-learning systems provide flexibility for teachers to create, manage, and administer online courses by implementing variety of activities such as assignments, forums and quizzes. In addition, e-learning system also allows the teachers to monitor student enrolment, their performance, progress, and grade (17). A study in Indian higher education system found that e-learning could be designed to suit individual need of the learners, provides easy access to the learning materials, and enables handicapped students (i.e. deaf and dumb) to learn (18). With all these advantages, the education system should complement the traditional face-to-face learning with e-learning. However, e-learning is not suitable for certain courses such as engineering skills that require hands-on or practical works because it is hard to learn skills through online learning resources (16).

In Malaysia, e-learning at public universities has started in year 2000 (19). Studies by $(20,21)$ at several universities in Malaysia indicated that to encourage the use of IT and e-learning approaches to teaching, the administrators should develop staff development programs and create a reward system. The authors also reported that most lecturers are reluctant to adopt e-learning due to lack of time and technical knowledge. These findings show that it is important to provide training when new teaching and learning methods and technologies are introduced.

Another online learning resource is $\mathrm{OCW}$, which is a collection of educational materials that can be used freely by the users (i.e. teachers, lecturers and students). The users are encouraged to use, reuse, redistribute and modify the materials for noncommercial purposes ((22); https://ocw.mit.edu). OCW was first launched by Massachusetts Institute of Technology (MIT) in 2001 with 50 courses where the core teaching materials which include syllabi, lecture notes, assignments and exams were virtually published(23) Currently, MIT-OCW is accessed by educators (9\%), students $(42 \%)$ and self-learners $(43 \%)$ from all over the world where it receives over 2 million visits every month(23). This statistic indicates that more and more people are using the online learning resources. Other higher education institutions also offer their OCW to be accessed by the community, for example, University of Cantabria, Spain in 2007 (22) and Universiti Teknologi Malaysia, Malaysia in 2012 (1).

In 2010, a new educational online tool which is more interactive and dynamic, known as Massive Open Online Courses (MOOC) was introduced (22). MOOC is an online course which has assessment and accreditation, and is only available when the course is open (22). It is intended for thousands of simultaneous participants from different origins and with different backgrounds, education levels and language proficiencies (24) Following the global trend and government inspiration to implement blended learning approach, this university also encourages its academic staff to implement MOOC. MOOC is a free Web-based distance learning program that is designed for the participation of a large number of geographically spread students which requires learners to be more proactive in their education and in building their personal learning networks(1).

In addition, the university also started BLOSSOMS project in collaboration with MIT in year 2013. China, Jordan, and Pakistan are among the countries that collaborate with MIT in BLOSSOMS project(25). BLOSSOMS is a video-based learning resource for teaching Science, Technology, Engineering and Mathematics (STEM) subjects (1). It complements the existing curriculum where the main focus is to enhance understanding about abstract concepts especially in STEM subjects. The lesson contents are separated in segments with learning activities in between which include exercises that encourage problem solving and critical thinking skills, and facilitated by the content experts(25).

All the aforementioned online learning and online learning resources indicate the development and innovation in higher education not only in Malaysia but also throughout the world. Apart from enhancing students' learning experience, online learning resources also benefits the academic staff by enhancing their knowledge through collaborating and sharing of new practices among the teaching community, be it at the national or international level. 


\section{Methodology}

This study used quantitative approach to collect data because it is more objective and enables selection of a representative sample. Guided by the definition of digital resources in the NALI Model, the research team developed the survey questionnaire. The survey questionnaire has three sections: Section A consists of five items on demographics, Section B has eleven items on awareness and usage of NALI pedagogy and online learning resources, whereas Section C consists of open-ended questions on the challenges and recommendations regarding NALI pedagogy and online learning implementation. Lecturers were asked to select the appropriate response for the demographics items. For the items on awareness, knowledge and usage, they were asked to rate their level of agreement using a 5-point Likert scale. However, this paper only discusses the results related to the use of NALI online learning resources. The pedagogical implementation of NALI will be discussed in another paper.

The survey was administered to 165 academic staff who taught at undergraduate and postgraduate level at seven schools/centres in a university campus in Kuala Lumpur, Malaysia in June 2017. The total number of responses obtained was 65 with a response rate of about $39 \%$.

Content validity of the survey questionnaire was examined by a panel of education experts. Statistical analysis was performed using the IBM Statistical Package for Social Science (SPSS) Version 18. Descriptive statistics was used to explore and clean the data prior to analysis. Missing values, outlying values, and data entry errors were identified. The reliability of the questionnaire was measured by calculating Cronbach's alpha internal consistency index and was found to be adequately high $(\alpha=0.9)$. Univariate analyses such as frequency and percentages were used to describe respondents' demographics, the level of awareness and usage of NALI online learning resources. In addition, cross tabulation analysis was also performed to determine the relationship between training and usage of online learning resources.

The following definitions of NALI digital resources were included as an attachment in the survey questionnaire to ensure comparable understanding of the respondents (1).

(i) e-Learning: a process of teaching and learning through electronic media.

(ii) Open Courseware (OCW): a collection of high-quality digital learning courses offered by the university. OCW learning materials include lecture notes, lesson plans and training questions which can be accessed by all Internet users.

(iii) Massive Open Online Course (MOOC): a free Web-based distance learning program that is designed for the participation of a large number of geographically dispersed students.

(iv) BLOSSOMS: a video-based learning resource that complements the existing curriculum for learning Science, Technology, Engineering and Mathematics subjects in collaboration with Massachusetts Institute of Technology.

(v) Edutainment: highlights the combination of education and entertainment elements (edutainment) to make a lesson fun and entertaining.

(vi) Video of Exemplary Professionals (VoEP): a collection of videos showcasing knowledge and skills by experts in various fields from around the world. It is a dedicated videosharing platform, devoted to spreading ideas, usually in the form of short, powerful talks or professional videos focussing on engineering and technology topics.

\section{Results and Discussions}

This section presents the results and discussions of the study.

\subsection{Demographic Profile}

The demographic profile of the respondents is shown in Table 1.

Table 1: Demographic Profile of Respondents

\begin{tabular}{|c|c|c|}
\hline Item & Description & Percentage \\
\hline \multirow{2}{*}{ Gender } & Male & 44.6 \\
\hline & Female & 55.4 \\
\hline \multirow{5}{*}{ Age group } & Below 25 & 0 \\
\hline & $25-29$ & 3.1 \\
\hline & $30-39$ & 29.7 \\
\hline & $40-49$ & 31.2 \\
\hline & Above 50 & 35.9 \\
\hline \multirow{2}{*}{$\begin{array}{l}\text { Highest academic } \\
\text { qualification }\end{array}$} & Master & 6.2 \\
\hline & $\mathrm{PhD}$ & 93.8 \\
\hline \multirow{4}{*}{ Designation } & Lecturer & 7.7 \\
\hline & Senior lecturer & 55.4 \\
\hline & Associate professor & 21.5 \\
\hline & Professor & 15.4 \\
\hline \multirow{5}{*}{$\begin{array}{c}\text { Teaching } \\
\text { experience }\end{array}$} & Less than 3 years & 18.2 \\
\hline & $3-10$ years & 18.2 \\
\hline & $11-18$ years & 30.3 \\
\hline & $19-26$ years & 19.7 \\
\hline & More than 26 years & 13.6 \\
\hline
\end{tabular}

The demographic profile is based on 65 respondents. The majority of the respondents aged 30 and above, and have doctoral qualifications. In addition, they have taught more than 10 years. Thus, most of them are quite experienced and may have seen various changes in the different types of online learning resources available for use.

\subsection{Awareness of NALI Online Learning Resources}

The academic staff awareness of NALI online learning resources was measured using a 5-point Likert scale: 1 (never heard), 2 (only know the term), 3 (know a little bit), 4 (know moderately), 5 (know very well). A respondent was considered to be aware of the online learning resources if he/she responded with at least scale 2 (only know the term). Table 2 presents the percentage of respondents who were aware of a particular online learning resource.

Table 2: Respondents' awareness of the online learning resources

\begin{tabular}{|c|c|c|}
\hline \multirow{2}{*}{ NALI online learning resources } & \multicolumn{2}{|c|}{ Awareness } \\
\cline { 2 - 3 } & Frequency & Percentage \\
\hline e-learning & 64 & 98.4 \\
\hline OCW & 50 & 76.2 \\
\hline MOOC & 51 & 78.1 \\
\hline BLOSSOMS & 46 & 74.2 \\
\hline Edutainment & 43 & 65.6 \\
\hline Video of exemplary professioals & 39 & 61 \\
\hline
\end{tabular}

The percentage of respondents who were aware of each the online learning resources was at least $61 \%$. The highest percentage was for e-learning, followed by OCW, MOOC, BLOSSOMS, and Edutainment. Announcements in the university website, in emails broadcasting training courses, during courses and seminars, and information in books published by the university have helped increase the awareness towards these online learning resources.

\subsection{Usage of NALI Online Learning Resources}

The percentages of respondents who have used a particular online learning resource at least once in their teaching are shown in Figure 2 . The most used resource is e-learning $(89.2 \%)$, followed by video of exemplary professionals (23.1\%), and MOOC (7.7\%). Elearning is one of the earliest online learning resources introduced to academic staff, and thus most of them have used it in their teaching. 


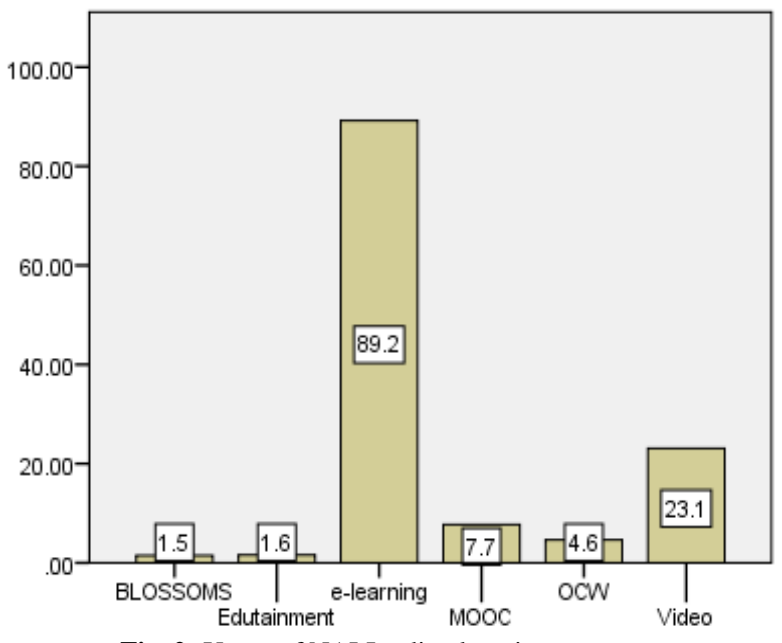

Fig. 2: Usage of NALI online learning resources

Newer online learning resources such as BLOSSOMS, OCW, MOOC, and Edutainment were used by less than $10 \%$ of the respondents. This is because most academic staff need to attend training on the newer and innovative resources before they can use them in their classes $(10,20)$.

\subsection{Training on NALI Online Learning Resources}

Table 3 shows the number and percentage of respondents who have attended and who would like to attend the training. Over $80 \%$ of respondents have attended training on e-learning, whereas only around $15 \%$ of the respondents have attended training on the other online learning resources. Thus, it is expected that the usage of these newer resources is low. Even though academic staff are regularly offered to attend training on using the online learning resources, not many have attended these training courses for some reasons. Intention to attend training on the newer resources such as OCW, MOOC, BLOSSOMS and Edutainment is moderate with a mean percentage of $30 \%$.

Table 3: Training on NALI online learning resources

\begin{tabular}{|c|c|c|c|c|}
\hline \multirow{2}{*}{$\begin{array}{c}\text { NALI online learning } \\
\text { resources }\end{array}$} & \multicolumn{2}{|c|}{$\begin{array}{c}\text { Have attended } \\
\text { training }\end{array}$} & \multicolumn{2}{c|}{ Wish to attend training } \\
\cline { 2 - 5 } & Frequency & $\%$ & Frequency & $\%$ \\
\hline e-learning & 54 & 83.1 & 6 & 9.2 \\
\hline OCW & 4 & 6.2 & 20 & 30.8 \\
\hline MOOC & 10 & 15.4 & 24 & 36.9 \\
\hline BLOSSOMS & 10 & 15.4 & 15 & 23.1 \\
\hline Edutainment & 0 & 0 & 19 & 29.2 \\
\hline
\end{tabular}

\subsection{Relationship between Training and Usage of Online Learning Resources}

Cross tabulation analysis was performed to investigate whether there is a relationship between attending training with the frequency of using the online learning resources. The Pearson Chi-Square values indicated that there was a significant relationship only for MOOC, whereas for other resources such as e-learning, OCW, and BLOSSOMS, there was no significant relationship as shown in Table 4.

Table 4: Relationship between training and frequency of resource usage

\begin{tabular}{|c|c|l|}
\hline $\begin{array}{c}\text { NALI online learning } \\
\text { resources }\end{array}$ & $\begin{array}{c}\text { Chi-Square } \\
\text { Significance } \\
\text { Value }\end{array}$ & \multicolumn{1}{|c|}{ Conclusion } \\
\hline e-learning & 0.704 & No significant relationship \\
\hline OCW & 0.65 & No significant relationship \\
\hline MOOC & 0.003 & $\begin{array}{l}\text { Significant relationship } \\
\text { exists }\end{array}$ \\
\hline BLOSSOMS & 0.667 & No significant relationship \\
\hline
\end{tabular}

Table 5 shows the cross tabulation output for MOOC. Since the Chi-Square significance value is 0.003 (as shown in Table 6), which is less than the cut-off p-value of 0.05 , the null hypothesis that claims there is no relationship between the frequency of using MOOC and the training of MOOC is not accepted. Hence, it can be concluded that training on MOOC does affect the frequency of using MOOC in teaching.

Table 5: Frequency Implement MOOC * MOOC Cross tabulation

\begin{tabular}{|c|c|c|c|c|c|}
\hline & & & \multicolumn{2}{|c|}{ MOOC } & \multirow{2}{*}{ Total } \\
\hline & & & Yes & No & \\
\hline \multirow{6}{*}{$\begin{array}{c}\text { Frequency } \\
\text { implement } \\
\text { MOOC }\end{array}$} & \multirow[b]{2}{*}{ Never } & Count & 8 & 52 & 60 \\
\hline & & $\begin{array}{c}\% \text { within } \\
\text { MOOC }\end{array}$ & $80.0 \%$ & $94.5 \%$ & $92.3 \%$ \\
\hline & \multirow{2}{*}{$\begin{array}{c}1-5 \\
\text { times }\end{array}$} & Count & 0 & 3 & 3 \\
\hline & & $\begin{array}{l}\% \text { within } \\
\text { MOOC }\end{array}$ & $0.0 \%$ & $5.5 \%$ & $4.6 \%$ \\
\hline & \multirow{2}{*}{$\begin{array}{l}11-15 \\
\text { times }\end{array}$} & Count & 2 & 0 & 2 \\
\hline & & $\begin{array}{c}\% \text { within } \\
\text { MOOC }\end{array}$ & $20.0 \%$ & $0.0 \%$ & $3.1 \%$ \\
\hline \multirow{2}{*}{\multicolumn{2}{|c|}{ Total }} & Count & 10 & 55 & 65 \\
\hline & & $\begin{array}{c}\% \text { within } \\
\text { MOOC }\end{array}$ & $100 \%$ & $100 \%$ & $100 \%$ \\
\hline
\end{tabular}

Table 6: Chi-square tests
\begin{tabular}{|l|c|c|c|}
\hline & Value & df & $\begin{array}{c}\text { Asymptotic signifi- } \\
\text { cance (2-sided) }\end{array}$ \\
\hline Pearson Chi-square & $11.739^{\mathrm{a}}$ & 2 & .003 \\
\hline Likelihood ratio & 8.691 & 2 & .013 \\
\hline $\begin{array}{l}\text { Linear-by-linear as- } \\
\text { sociation }\end{array}$ & 8.156 & 1 & .004 \\
\hline N of valid cases & 65 & & \\
\hline
\end{tabular}

a. 4 cells $(66.7 \%)$ have expected count less than 5 . The minimum expected count is .31

\subsection{Advantages and Disadvantages of Using NALI Online Learning Resources}

Each of the online learning resources has its advantages and disadvantages. The advantages mentioned by the respondents are listed in Table 7. Respondents were requested to indicate their responses on a 5-point Likert scale: 1 (Strongly Disagree), 2 (Disagree), 3 (Somewhat Agree), 4 (Disagree), 5 (Strongly Agree). Only the cumulative percentages of at least a 3 (Somewhat Agree) are shown in Table 7. The results indicate that more than $80 \%$ of respondents agreed that resources such as e-learning and OCW promote lifelong learning, increase students' motivation to learn, reduce learning time, encourage independent learning among the students, and allow self-paced learning.

Table 7: Advantages of using NALI online learning resources

\begin{tabular}{|l|c|c|}
\hline \multicolumn{1}{|c|}{ Item } & e-learning (\%) & $\begin{array}{c}\text { Open Course } \\
\text { Ware (\%) }\end{array}$ \\
\hline Promotes lifelong learning & 90.6 & 94.4 \\
\hline Increases motivation & 84.3 & 97.3 \\
\hline Reduces learning time & 94.2 & 95 \\
\hline Encourages networking & 78 & 82.0 \\
\hline Encourages independent learning & 92.3 & 94.3 \\
\hline Allows self-paced learning & 88 & 97.1 \\
\hline
\end{tabular}

Table 8 shows the percentages of respondents who opined that elearning has several disadvantages such as limited access, students do not participate, confusing, less efficient learning, and learning can be difficult. This could be because the internet connection for e-learning is dependent on the university network capability, and there is little monitoring or assistance at hand during students' independent learning. It should be noted that the respondents did not declared the disadvantages of other resources. This is because most of them did not use the other resources as discussed in Section 4.3. 
Table 8: Disadvantages of using NALI online learning resources

\begin{tabular}{|l|c|}
\hline \multicolumn{1}{|c|}{ Item } & e-learning (\%) \\
\hline Limited Access & 74 \\
\hline Students do not Participate & 74.5 \\
\hline Confusing & 63.3 \\
\hline Learning is Less Efficient & 60 \\
\hline Learning is Difficult & 74 \\
\hline
\end{tabular}

\section{Conclusion}

The findings of this research indicate that many respondents were aware of NALI online learning resources. Most of them only attended training on e-learning, and are currently implementing it in their courses. The use of NALI online learning resources, particularly e-learning and OCW has certain advantages such as reducing learning time, encouraging independent learning and promoting life-long-learning. Therefore, the management should promote the use of other resources (i.e. OCW and MOOC) in the teaching and learning while making effort to overcome the challenges. The training centre should organize more training and workshops on new online learning resources to the academic staff to increase their knowledge and skills in using them.

\section{Acknowledgement}

This research work is funded by GUP (GUP: Q.K130000.2640.12J91) and supported by RMC. We would like to thank all the academic staff who participated in this research.

\section{References}

[1] Innovation NAL. 2018

[2] Alias RAaA, B. A Guide to New Academia Learning Innovation. Perpustakaan Negara Malaysia. 2016.

[3] Byard M. IT under school-based policies for Initial Teacher Training. Journal of Computer Assisted Learning. 1995;11(3):12840.

[4] 4Veen W. The role of beliefs in the use of information technology: implications for teacher education, or teaching the right thing at the right time. Journal of Information Technology for teacher education. 1993;2(2):139-53.

[5] Wild M. Technology refusal: Rationalising the failure of student and beginning teachers to use computers. British Journal of Educational Technology. 1996;27(2):134-43.

[6] Shah GUD, Bhatti MN, Iftikhar M, Qureshi MI, Zaman K Implementation of technology acceptance model in e-learning environment in rural and urban areas of Pakistan. World Applied Sciences Journal. 2013;27(11):1495-507.

[7] Oliver R. Factors Influencing Beginning Teachers' Uptake of Computers. Journal of Technology and Teacher Education. 1994:2(1):71-89.

[8] Downes T. Student-teachers' experiences in using computers during teaching practice. Journal of Computer Assisted Learning. 1993;9(1):17-33.

[9] Dunn S, Ridgway J. Computer use during primary school teaching practice: a survey. Journal of Computer Assisted Learning. 1991;7(1):7-17.

[10] Mundy M-A, Kupczynski L, Kee R. Teacher's perceptions of technology use in the schools. Sage Open. 2012;2(1):2158244012440813

[11] Siti Syahirah S. VLE Frog tingkat minat bidang STEM. Berita Harian. 2017.

[12] Frogasia. Malaysians can now learn anywhere, anytime. 2018

[13] Nikian S, Nor FM, Aziz MA. Malaysian teachers' perception of applying technology in the classroom. Procedia-Social and Behavioral Sciences. 2013;103:621-7.

[14] Xu D, Jaggars SS. Adaptability to Online Learning: Differences across Types of Students and Academic Subject Areas. CCRC Working Paper No. 54. Community College Research Center, Columbia University. 2013.

[15] Flora McMartin EIWMMM. International Journal on Digital Libraries. 2018;9(1):65-79.

[16] LLC E. E-Learning: Concepts, trends, applications. 2018
[17] Ahmad NB, Ishak MK, Alias UF, Mohamad N. An Approach for E-Learning Data Analytics using SOM Clustering. International Journal of Advances in Soft Computing \& Its Applications. 2015;7(3).

[18] Gulavani S. E-Learning in Indian Higher Education System.

[19] Hussain RMR. E-learning in higher education institutions in Malaysia. E-mento. 2004;5(7):72-5

[20] Puteh $M$, editor E-LEARNING IN MALAYSIAN PUBLIC UNIVERSITIES: CASE STUDIES OF UNIVERSITI KEBANGSAAN MALAYSIA AND UNIVERSITI TEKNOLOGI MALAYSIA1. Paper presented at the 1st International Malaysian Educational Technology Convention; 2007.

[21] Thinakaran R, Ali R. Programming Tutoring Systems and Motivation Assessment Model. Advanced Science Letters. 2017;23(4):2709-12.

[22] Martinez S. OCW (OpenCourseWare) and MOOC (open course Where?). Proceedings of OpenCourseWare Consortium Global. 2014.

[23] Ware MOC. 2018.

[24] Daradoumis T, Bassi R, Xhafa F, Caballé S, editors. A review on massive e-learning (MOOC) design, delivery and assessment. P2P, Parallel, Grid, Cloud and Internet Computing (3PGCIC), 2013 Eighth International Conference on; 2013: IEEE.

[25] BLOSSOMS M. 2018 